\title{
MIEJSCE PAMIĘCI A \\ PRZESTRZENIE PAMIĘCI
}

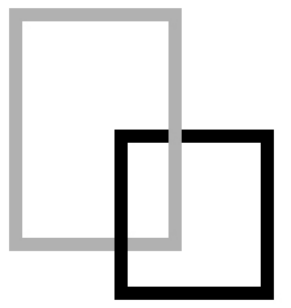

Memory places or areas of Memory

\section{Marek Barański*}

SUMMARY: Cultural Heritage consits among others of historic monuments and memorial places or sites. They honors both the material evidence and peoples testimony being of non material character. Its presentation in a proper manner should consider not only inclussion of a vast documentary materials as museal collection, but also create specific forms of their interpretation and presentation. Traveling to shear diffent areas of man's perception and intelectual interest can be creative and helpful in building the Memory of historic sites.

KEYWORDS: Architecture, memorial sites, holokaust, Auschwitz

Określenie Miejsce pamięci, to układ dwóch różnych pojęć odnoszących się do wąsko i szeroko rozumianej lokalizacji przedmiotu zainteresowania oraz do konceptu pamięci, który może być postrzegany jako forma przedstawiona bądź dokument. W najbardziej prostym podejściu możemy mówić o tym miejscu i tej pamięci. Jednak tej prostej definicji towarzyszy wiele aspektów mających wpływ na rozumienie samego miejsca, jak i naszych relacji w wypełnieniu takiej woli. Wydawać by się mogło, że proste przestawienie słów „miejsce” i „pamięć” i utworzenie określenia „pamięć miejsca” wiele nie zmienia. Jednak przeniesienie nacisku naszego zainteresowania z „miejsca” na „pamięc" powoduje olbrzymie rozszerzenie skali odniesień, choć dotyczą one tych samych elementów. W generalnym opisie, mówiąc o „miejscu pamięci” mamy na myśli miejsca o doniosłym przekazie pamięci, jednak nie wypełnia to rozumienia tego pojęcia. Najczęściej określenie miejsc ma stała topograficzną konotację, ale nie jest to warunek wymagany. Istotą pamięci jest wyrażona wolą pamiętania, lecz pamięć może być różna i odnosić się do różnych jej aspektów. Co więcej może być ona transferowana w kolejnych pokoleniach. Okazuje się, iż oba te pojęcia mogą mieć zarazem wymiar materialny i niematerialny, będąc faktem transcendentnym, mnemonicznym. Tym samym mogą powstawać szczególne sytuacje różnorakiego pojmowania czegoś, co określa się generalnie „miejscem pamięci”. Samo miejsce może się składać nie tyle $\mathrm{z}$ jednej, co z wielu lokalizacji, mających ten sam lub różny charakter. Taka obecność tworzyć może pewien zbiór miejsci dokumentów tyczących się tego miejsca i tej pamięci, co tworzyć może związane z nimi przestrzenie dookreślające pamięć i miejsce. Dodatkowo może się to również tyczyć aspektu niematerialnego i poza materialnego postrzegania miejsca. Mamy pamięć, którą możemy określić jako bezpośrednią i pośrednią. Co jest ciekawe, samo miejsce, jak i pamięć to obszary, które mogą ulec przekształceniu, a nawet zatarciu. Tym samym otrzymujemy swego

* Marek Barański, Faculty of Civil Engineering and Architecture, Kielce University of Technology https://orcid.org/0000-0001-8092-9108 
rodzaju konglomerat przekazu, który następnie w zależności od podejścia odbiorcy będącego jego świadomym jest gotowy przyjąć taki przekaz, lub nie będzie w stanie go odebrać, na skutek braku przygotowania lub uświadomienia jego przekazu. Pewien problem tworzyć mogą ci, którzy spotkają się z takim przekazem $\mathrm{w}$ formie częściowej, lub nie są w pełni przygotowani na odbiór tego rodzaju przekazu. Im „miejsce pamięci” powinno rozszerzyć możliwości poznania takiej pamięci. Sam przekaz materialny i niematerialno- transcendentny w odbiorze może mieć aspekty estetyczne, emocjonalne, duchowe i naukowe. Nie poruszyliśmy jeszcze kwestii adresata tego przekazu, którym może być osoba indywidulna lub zbiorowość, a także celu, mogącego wynikać zarówno $\mathrm{z}$ symbolicznego wspomnienia, jak i intencjonalnej potrzeby takiego upamiętnienia w jednym lub wielu miejscach, poprzez różne formy przekazu. W tym rozważaniu istotnym wydaje się kwestia przechodzenia indywidualnego wspomnienia w pamięć określaną jako zbiorowa, która może być budowana z wielu różnych i przeciwnych wspomnień. Okazuje się, iż taka potrzeba wspominania może tworzyć kolejne projekcje pamięci i miejsca. $\mathrm{W}$ tej egzemplifikacji przewija się kwestia zabytków, które również mogą posiadać materialną treść i być niematerialnym i pozamaterialnym przekazem. Te proste przedstawienie próbowało scharakteryzować naturę i skalę problemów wynikających z różnicy spojrzeń i doznań, z tym czymś, co nazywane jest generalnie „miejscem pamięci”. Pamięć może mieć też różne wymiary. W formie opisanej historii, będąc naukowym ujęciem ogólnie prezentowanym, jak również posiadać wymiar indywidualny, osobisty, gdzie skrywane przeżycia mogą być odczuwane. Pomiędzy tymi ekstremami mieści się to wszystko co wydarzyło się w jednoznacznie określonym miejscu, topograficznie określanego świata materialnego, bądź było zdarzeniem w wielowymiarowej przestrzeni świata niemierzalnego. Jak wspomniano powyżej, pamięć związana jest $\mathrm{z}$ faktem bycia oraz wolą pamiętania. Pojawia się także problem transferu pamięci budującej pamięć innych, co za sprawą zapisanej historii, czy innego przekazu będzie kreowało pamięć $\mathrm{w}$ innym miejscu.

Z problemem zapisu i przekazu pamięci o czynach wielkich osób starożytności i wydarzeniach mierzyli się już antyczni historycy. Potrzebę upamiętnienia miejsca związanego z przekazem pamięci mamy za sprawą rozwoju nowej chrześcijańskiej religii, kiedy to pojawi się pojęcie martyra i relikwii. W sztukach pięknych kwestia upamiętniania osób i wydarzeń uzyska formę przedstawień malarskich i rzeźb. W XX wieku z konceptem pamięci i jej społecznej relacji zmierzyła się w latach 30tych szkoła badawcza Annales, której jeden z czołowych przedstawicieli Maurice Halbwachs zdefiniował kwestię społecznych ram pamięci, przedstawiając relacje społeczne i wzajemne odniesienia ${ }^{1}$. Maurice Halbwachs wprowadzając pojęcie społecznych ram pamięci (les cadres sociales de la memorie), zauważył, że struktury społeczne kształtują co jest ważne i zapamiętywane przez członków poszczególnych społeczeństw i grup społecznych. Takie grupy wykorzystują przestrzenne odniesienia by móc zapamiętywać i poprzez to zaznaczać przestrzeń w której żyją. Uświadomiono sobie, że wspólna społeczna pamięć ma wymiar przestrzenny, zaś przestrzeń jest czymś stałym i umocowywanie w niej wspólnej pamięci pozwala danemu społeczeństwu tworzyć nośniki tradycji danej grupy. 
Dyskutując na temat „miejsca pamięci” nie możemy nie odnieść się do pojęcia wprowadzonego w latach 80 tych przez Pierre Nora $^{2}$. Nora wrazze swoim zespołem zaproponował koncepcję „miejsc pamięci” (Lieux de memoire), zmieniającą pole badawcze i tworząc inne ujęcie czasoprzestrzeni historycznej. Dla odróżnienia od ogólnie przyjętego określenia „miejsce pamięci” od miejsc pamięci wykreowane przez Pierre Nora, będę je przywoływał jako lieux de memoire, tak jak to autor użył w swej pracy. Te wyróżnienie ma swoje uzasadnienie. Jego koncepcja jednak nie jest próbą opracowania charakterystyki miejsca pamięci, lecz zwróceniem uwagi na kwestie rozdziału zinstytucjonalizowanej historii, interpretowanej przez historyków, od historii żywej zapisanej przez społeczeństwo w kreowanych przez siebie formach, czy tworzonych miejscach. Uzasadnienie zarysowanej koncepcji lieux de memoire poparte przykładami opublikowane w zbiorowym dziele zrobiło spore zamieszanie w różnych środowiskach będąc odbierane jako postmodernistyczne podejście rozumienia historii, czy przeszłości. Omówienie koncepcji wymaga dłuższej prezentacji, na którą w tej prezentacji nie ma czasu, dlatego zainteresowani będąc nie usatysfakcjonowani moimi interpretacjami mogą poznać komentarze innych autorów. Oczywiście warto zapoznać się z dziełem autora, lecz trzeba to zrobić w sposób świadomy najpierw poznając jego ogólną koncepcjąa a potem wchodzić stopniowo w prezentowane przykłady. Dlatego czytając prace poświęcone lieux de memoire warto zapoznać się z autorskim uogólnieniem koncepcji oraz prezentacją rozważań Nory przestawionej przez Paula Recoeura, który je egzemplifikuje dołączając zdawkowy komentarz ${ }^{3}$. Istotnym elementem lieux de memoire, na który warto zwrócić uwagę to problem nie tyle pamięci, co miejsca, co autor z jednej strony kwestionuje, z drugiej zaś przywołuje jako pamięć o konkretnej lokalizacji. Nie jest to proste dla czytelnika, który na bieżąco musi przełączać swą świadomość odnoszącą się do określenia lieux de memoire, kiedy ona materializuje się w jakimś konkretnym miejscu, bądź rozmywa się i dematerializuje odnosząc się do uogólnienia postrzegania takiego lieux de memoire. Ten problem, który nie rysuje się tak wyraźnie w rozumieniu języka francuskiego, dostrzegli Anglosasi, którzy wydając pracę Pierre Nora zatytułowali ją "The Realms of Memory”. Edytor dzieła Lawrence Kitzman mając świadomość braku topograficznych uwarunkowań dla idei lieux de memoire, użył tutaj słowa „realm”, które odnosi się do pojęcia „królestwo- obszar podległy władzy królewskiej, czy nadrzędnej", zaś liczba mnoga oznacza, że mamy do czynienia z wieloma, różnymi lecz współrównoważnymi tego rodzaju obszarami, czy dominiami. Dlatego po tym wydaniu pracy, dziwić może u wielu autorów tłumaczenie tego pojęcia na angielski jako „sites of memory”, które jedynie czasami dotyczą pamięci związanej z topograficzną lokalizacją. Dla nas, konserwatorów zabytków, istotne jest, że koncepcja ta bardzo powierzchownie dotyka problemu zabytków, choć one same jako obiekty materialne muszą przewijać się w tej pracy. Dla Nora zabytki to zaledwie jedna $\mathrm{z}$ form, do tego nie najważniejsza, odnosząca się do kwestii pamięci.

2 N. Pierre, ed. Les lieux de memoire, vol. I-VII, Gallimard, Paris 1984- 1992; ibid., Między pamięcia i historiq: les lieux de memoire (tł. M. Borowski, M. Sugiera) w: Didaskalia. Gazeta teatralna, nr 105, 10/2011, s.20-27.

3 P. Recoeur, Pamięć, historia, zapomnienie (tł. Margański J.), Universitas, Kraków 2006, s. 533-545.

4 N. Pierre, ed. D. Kitzman Lawrence, The Realms of Memory: the Construction of the French Past, vol. I-III, Columbia University Press, New York 1996-1998. 
Nora definiując lieux de memoire wskazał, że winno to być rozumiane jako „każda znacząca jednostka, o naturze materialnej bądź niematerialnej , która za sprawa zniszczenia na skutek ludzkiej woli, bądź za sprawą upływu czasu, stały się elementami dziedzictwa pamięci każdej społeczności, by połączyć ją razem przez przywołanie niewidocznych łączników" Wo Wola pamiętania musi zapoczątkować proces określania takiego lieu. Bez tego kryterium definicja byłaby za szeroka i objęłaby każdy obiekt warty wspominania, co tworzyłoby z lieux de memoire tylko lieux d'historie. W odniesieniu do miejsc archeologicznych Nora zauważa, że chociaż wiele z nich zatraciło element pamięci i intencji pamiętania, ta nieobecność jest kompensowana przez pracę czasu i wiedzy. W przyjętej przez Nora koncepcji dziedzictwo kultury jest pojęciem kreowanym przez fakt przechodzenia i stawania się na różnych poziomach. Gdzie dziedzictwo narodowe staję dziedzictwem symbolicznym i utożsamianym, gdzie przejście również może następować pomiędzy dziedzictwem materialnym, dostrzeganym i niematerialnym, odczuwanym. Opierając się na koncepcji lieux de memoire możemy pamięć wiązać nie tylko z określonymi miejscami, lecz przestrzeniami związanymi z ważnymi wydarzeniami, będących $\mathrm{w}$ swych różnych warstwach zapisem historii, zabytkiem architektonicznym napełnionym wytworami sztuki i kultury materialnej, pamiątkami różnej klasy i rodzaju, gdzie dokonuje się utrwalanie obyczaju, tradycyjnych strojów, dawnej muzyki, co wypełnia przestrzeń dziedzictwem niematerialnym, i będzie odczuwane jako pozamaterialne oddziaływanie materii zabytków. Dlatego też dookreślenie pamięci będące aktem historycznej materializacji stanowić może o jakości przekazu takiego miejsca i związanej z nim pamięci.

Warto również zauważyć, że kwestiami pamięci, jej realizacji i rozumienia poza Norą analizowało wielu autorów. Frances Yeats, która wprowadziła określenie arsmemoriae, zauważyła, że określone miejsca są wielokrotnie częściej wykorzystywane w systemie zapamiętywania niż przestrzenie architektonicznie nie określone ${ }^{6}$. To także kwestia genius loci wprowadzona przez Christiana Norberg Schultza szukająca związków przeszłości w dziedzictwie architektonicznym społecznie rozpoznawalnym ${ }^{7}$. Marianne Hirsch, wprowadzając pojęcie „postpamięci”, zajęła się problemem przekazu pamięci i jej dziedziczenia w kolejnym pokoleniü. Jan Assmann wprowadził pojęcie „pamięci kulturowej”, będącej alternatywą dla „pamięci komunikatywnej”" amięć kulturową według niego jest potrzebą zapisywania przeżyć w książkach, rytuałach, sztukach performatywnych, tworząc pamięć narodową, kreowaną politycznie. Zaś pamięć komunikatywna to wybiórcze przekształcanie przeżyć w pamięć, stając się wolą przejmowania jej bezkrytycznie. Paul Recouer szeroko rozważając problematykę pamięci i historii komentował kwestię wymazywania pamięci i zapominania ${ }^{10}$. Zauważa problem konkretyzacji przekazu nawet w formie aluzyjnej, odnoszącej się do określanej przestrzeni. Należy również wspomnieć

5 N. Pierre, Kitzman L., Realms of Memory, op.cit... s. XVII.

6 F. Yates, Sztuka pamięci, (tł. W. Radwański), PiW, Warszawa 1977.

7 C. Norberg Schultz, Genius loci: Toward a Phenomenology of Architecture, Rizzoli, New York 1980.

8 M. Hirsch, Pokolenie postpamięci, w: Didaskalia Gazeta Teatralna, nr 105 10/2011, s. 28-26.

9 J. Assmann, Pamięć zbiorowa i tożsamość kulturowa (tł. S. Dyroff, R. Żytyniec), w: Borussia 29/2003 s. 11-16.

10 P. Recoeur, op.cit..s. 547-600. 


\section{Miejsce pamięci a przestrzenie pamięci}

przemyślenia Mariana Kuli na temat przekazu historii poprzez „nośniki pamięci”, którymi są również zabytki ${ }^{11}$. Mając świadomość ogromu refleksji na temat oddziaływania nie tylko pamięci, lecz również przeżyć w szerszym i jednostkowym odniesieniu, jako doświadczenia psychologicznego. Autorów tych przywołałem bo w jakiś sposób w ich dokonaniach zanurzam swoje myślenie o zabytkach, jako formach pamięci i jej lokowaniu. W znaczący sposób odciska się to w doznawaniu zabytków, co pozwoliłem sobie określić jako dziedzictwo pozamaterialne ${ }^{12}$.

Koncepcja ujęcia lieux de memoire pobudziła zainteresowanie specjalistów różnych kierunków humanistyki ${ }^{13}$. Wydawało się, że w prosty sposób można anektować tę koncepcję historyczno - socjologiczna na użytek wartościowania czy definiowania form ochrony zabytków ${ }^{14}$. Okazało się, że tego rodzaju definiowanie przeszłości i miejsca, nie da się w prosty sposób przełożyć i dopasować do wdrożonego od dawna systemu postrzegania zabytków i miejsc historycznych. Wraz z przyjęciem Konwencji UNESCO Dziedzictwa Niematerialnego dotyczącej utrwalenia tradycji obyczaju, obrządku zagrożonej wyginięciem, bądźzatratą pojawiły się również możliwości innego spojrzenia na dziedzictwo kultury. Konwencja Dziedzictwa Niematerialnego otworzyła drzwi do przyjęcia form ochrony i konserwacji, które ze względu na swą kulturową tradycję nie mieściły się w tzw. tradycyjnym europejskim podejściu. Konwencja ta usankcjonowała wcześniejsze działania i postrzeganie ochrony zabytków poza jej materialny wyraz. Walnie przyczyniła się tutaj Karta z Burra określając za zabytkowe, przestrzenie socjalne uznane. Pojawienie się koncepcji teatralizacji czy renancementu dziedzictwa, zwaną również ożywianiem historii wydawało się, że jest to sposób na powiazanie historii i miejsca w różnych aspektach. Będąc szeroko przyjmowana, dla wielu staję się panaceum na problemy związane także z ochroną zabytków, kiedy to wzbudza się zainteresowanie przeszłością. Jednak, czy okazjonalne lub raz w roku zorganizowanie takiego teatralnego przedstawienia ma załatwić brak oddziaływania przeszłości na co dzień? Kolejnym problemem jest poszukiwanie formy plastycznej dla rzeczy minionych. Proste i komunikatywne przedstawienie w opinii estetów i krytyków sztuki nie nabiera cech artystycznego wyrazu. Tworzone są formy spektakularne, które prostej opowieści mają nadać cech wyjątkowych. Choć takie aktywne podejście otworzyło kolejne drzwi w procesie przybliżania historii i dziedzictwa społeczeństwu, lecz nie wiele ma ono wspólnego z ochrona i konserwacją zabytków. Nie będąc przeciwnym tego rodzaju zabawie

11 M. Kula, Nośniki pamięci historycznej, DiG, Warszawa 2002.

12 M. Barański, Pozamaterialne i nieobecne dziedzictwo kultury, Ochrona zabytków, 3/2005, s. 49-55; ibidem, Extra material heritage in historic monuments preservation, w: [red.] A. Kadłuczka, Karta Krakowska 2000. Dziesięć lat później, Politechnika Krakowska, Kraków 2011, s.13-16.

13 A. Szpociński, Miejsca pamięci (Lieux de memoire), Teksty Drugie, 4/2008, s.11-20; S. Staszczyk, A. Stępniak, Pamięć i miejsce pamięci w dydaktyce historii, w: ed. J. Brudzińska, J. Strykowska, Współczesna edukacja historyczna. Doświadczenia i oczekiwania, UAM Poznań 2005, s. 171-188; M. Delapierre, Miejsca pamięci czy pamięć miejsc? Kilka refleksji na temat uobecniania przeszłości w literaturze wspótczesnej, w: Ruch Literacki r. LIV 2013, z. 1(316), s. 49- 61.

14 A. Tomaszewski, Polskie miejsca pamięci według Adama Miłobędzkiego, Rocznik Historii Sztuki 30/2005 s. 285-290; red. R. Traba, H. H. Hahn, Polsko - niemieckie miejsca pamięci, t. 2, Warszawa 2015, t. 3, Warszawa 2012, t. 4, Warszawa 2013. 
czy adaptacji przeszłości, warto głębiej spojrzeć w kwestie pojęć - pamięć, miejsce, przestrzeń, dziedzictwo, by móc dopasować przyjmowaną formę do treści przekazu. Okazuje się, że obecne, potoczne rozumienie miejsca pamięci daleko już odbiegło od swego pierwowzoru i zaczyna być naginane do celów, jakim nie było przeznaczone. Widać to nawet w prostym i trochę naiwnym przyjmowaniu samej nazwy, która przez samego Philipa Nora była postrzega jako coś więcej niż topograficzne miejsce i osadzona w historii pamięć. Zanurzmy się w te kwestie, by starać się odnaleźć sens historycznego przekazu jakim są zabytki. W naszych działaniach podnosimy kwestie prezentacji pamięci w zabytkach i pamięci zabytków, takimi jakie one kiedyś były. Nie mniej ważnym jest upamiętnianie w przestrzeni dziedzictwa wydarzeń i tutaj pojawia się problem. Na ile przekaz artystyczny może równoważyć przekaz historyczny lub być dokumentem.

Konserwatorzy zabytków z natury swojej pracy też dotykają kwestii pamięci, którą w zależności od powierzonej im roli mogą wypełniać aktywnie poprzez określanie zakresu korzystania i prezentacji zabytku. Mogą to również zrobić biernie, gdy dobierają najbardziej optymalne technologie i formy działań zabezpieczających i konserwatorskich. By jednak swą rolę dobrze móc zrealizować konserwator musi mieć właściwe podejście i rozumienie zabytku, gdzie należy zagłębić się w jego istotę, by nie popełnićbłędu, a także musi zagłębićw sposób postrzegania i kontaktu potencjalnego odbiorcy z zabytkiem. Przepraszam, popełniłem dramatyczny błąd. Po roku 1980 my już nie zajmujemy się materialnymi zabytkami lecz dziedzictwem, które ma wieloaspektowy wymiar. Dlatego też nam konserwatorom poszukującym mocnych i trwałych postaw merytorycznych dla swych działań tak trudno jest oprzeć się na koncepcji Philipa Nora. Nora opracowując swoją koncepcję odnosił do XX wiecznego rozumienia historii i przeszłości, która w tym czasie przeżywała swoje problemy interpretacyjne. Problemy te po ponad ćwierćwieczu dalej istnieją choć już w zmienionej formie i bardziej złożonej sytuacji. Prawdopodobnie pisząc swą pracę w dzisiejszej Francji musiałby się zmierzyć z rozbieżnymi kwestiami identyfikacji, gdzie Pieśń o Rolandzie (la Chanson de Roland) może nabierać nowych znaczeń i być przywoływana jako kolejne les lieux de memoire. Ale to tak na marginesie. Nam środkowym Europejczykom przychodzi zmierzyć się z własnymi lieux de memoire, które jako żywo nie dotyczą jedynie przestrzeni ograniczonej Bugien i Odrą, lecz wychodzą na znacznie szersze przestrzenie zarówno w materialnym jak i transcendentnym wymiarze.

Pierre Nora w 2007 roku, po dwudziestu latach wydał pracę komentując kwestie europejskiego podejścia do tego rodzaju interpretacji przeszłości zaznaczył, iż każdy kraj charakteryzują właściwe mu rodzaje relacji z przeszłością ${ }^{15}$. Każdy kraj Europy na swój sposób musi spojrzeć we własną przeszłość redefiniować tożsamość, mając na względzie doznane traumy. Zauważył jednak, że sednem jest dialektyczna relacja między tym co uniwersalne i tym co specyficzne, co wyjaśnia bowiem i warunkuje samo pojęcie lieu de memoire. Tożsamość kulturową Europy odniósł do 7 możliwych kategorii europejskich lieux de memoire. Określił je jako następujące lieux:

- historiograficzne - budujące naszą wiedzę o przeszłości, który są podręczniki szkolne, 
muzea czy centra interpretujące przeszłość,

- fundacyjne - rozumiane jako epoki i ruchy stanowiące o nowym podejściu estetyczno - społecznym

- decydujące - mające przełomowe znaczenie militarne, bądź dyplomatyczne

- geograficzne - które poprzez swą naturę łączą lub wydzielają

- kulturowe i ekonomiczne - będące m.in. centrami wymiany handlowej i naukowej, rynkami, szlakami handlowymi;

- twórcze naukowo - interpretowanymi z symbolami nauki, ośrodkami badawczymi i artystycznymi;

- symboliczne - które są związane z paneuropejskim rozumieniem religii i świadomości.

Zapis tego punktu musze zacytować w pełnym brzmieniu, bo dalej będę się do niego odnosił „od wielkich peregrynacji religijnych (Świętego Jakuba z Compostelli po Lourdes), poprzez podróże turystyczne, aż po miejsca związane z europejską świadomością: Deklaracja Praw Człowieka, Auschwitz”. Do umieszczenia w tym miejscu KL Auschwitz będę się za chwile krytycznie odnosił.

Co ciekawe, problem lieu de memoire jakim jest KL Auschwitz nie pojawił się w pierwotnej pracy Pierra Nora, gdzie cytowanych jest ponad 100 przykładów odniesień pamięci Francji. Podnosząc jako znaczący w pamięci Francji mord na paryskich komunardach, nie ustosunkował się do innej zbrodni o nie spotykanym dotąd wymiarze. Z tego powodu był krytykowany, gdyż jednak trochę Francuzów zostało wysłanych przez innych Francuzów z biletem w jedną stronę by peregrynowali do tego miejsca gdzieś na wschodzie ${ }^{16}$. Nora komentując tę kwestię odniósł się do problemu określając, iż totalitarna rzeczywistość nie może być sprowadzana do jednego zmityzowanego miejsca. Jednak ostatecznie uznał to jako miejsce o znaczeniu symbolicznym. Wprowadzenie przez Pierre Nora w tym zestawieniu KL Auschwitz jako miejsca symbolicznego uważam za błędną interpretację, gdyż znacząco lepszym byłoby uznanie Holocaustu, jako znaczącej europejskiej pamięci fundacyjnej obejmującej różne lokalizacje od Atlantyku po Don, której pamięć i post pamięć objęła bez małą całą kulę ziemską. KL Auschwitz byłby zaledwie jednym z licznej egzemplifikacji takiego lieux. Widzenie zbrodni Holocaustu poprzez KL Auschwitz zawęża problem i jego skalę. KL Auschwitz, a także inne obozy śmierci czy miejsca kaźni to lokacje paradoksalne, które były, lecz ich nie ma. Oczywiście mogą być tematem rozważań historyków, gdzie będą analizowane dokumenty, wspomnienia w różnym układzie zapisu pamięci ${ }^{17}$. Taka analizę można podejmować z pozycji analizy socjologicznej osobistych i zbiorowych odniesień. Proste ściany obozowego baraku, czy puste pole to nie miejsca tragedii, lecz zaledwie jej ramy. Bez przekazu o dokonanej zbrodni to zaledwie zabytki, miejsca konserwatorsko znaczące, które dopiero napełniane nie tyle pamięcią, co przekazem dziedzictwa nabierają dopiero znaczenia. KL Auschwitz, posiada szczytowe znaczenie w tym

16 M. Delaperriere, Miejsca pamięci czy pamięć miejsc, op.cit..., s. 55.

17 C. Meier, Od Aten do Auschwitz. Rozważania nad kondycją historii, (tł. Artrwińska A.),Wydawnictwo Poznańskie, Poznań 2013. 
przekazie o dramacie który odbywał się nie tyle w geograficznie określonej Europie, co wśród ludzi zamieszkujących tę przestrzeń. To również problem, że jedni w tej konfiguracji byli bliżej, drudzy dalej. Jedni dotknęli zła, inni o nim słyszeli. Jednak te miejsca stanowią coś więcej niż określone punktowe cmentarze, czy obozy. Oczywiście wprowadzenie Holocaustu pomiędzy inne miejsca fundacyjne jakie dla Europy egzemplifikował Nora: „Antyk, Renesans, Reformacja, Oświecenie, Rewolucja Francuska, nacjonalizm, imperializm”, burzyłoby by koncepcję pamięci mogącej być określoną jako budującą. Możliwe, że z perspektywy Francji, nie jest to, aż tak znaczące lieux de memoire. Postrzegane z perspektywy nie tylko ofiar hitleryzmu, ale mieszkańców Polski, gdzie o taką pamięć i o takie miejsca co dzień się ocieramy, jest to znaczące by było uznane za trwałe doświadczenie i pamięć, do której każde następne pokolenie będzie się musiało odnosić. Holocaust z jednej strony, a z drugiej Sybir, co proszę zauważyć nie odnoszę do regionu geograficznego nazywanego Syberią, to realna pamięć, która odcisnęła się społecznie nie gorzej niż pamięć Komunardów Paryskich dla Francuzów, którą Nora uznał za lieux de memoire. Lecz kto pamięta o XIX i XX wiecznej tragedii Sybiru? My Polacy i kilku bezkompromisowych Rosjan. Dla nas to znaczące miejsce męki w wykuwaniu już od dwustu lat narodowej wolności. Dla Rosjan to miejsce szczęśliwe w nieszczęściu, bo car i Stalin magli prosto ubit. I ubijali, o czym wiedzą wszystkie narody żyjące na Wschodzie Europy. Tylko bezczelności Sowietów zawdzięczamy to, że mamy nasze Miejsca Pamięci w Katyniu, Bykowni, Charkowie, czy Miednoje. Wizja podbitego na wsiegda świata zaślepiła decydentów i sprawców. Bo gdyby byli bardziej roztropni i przebiegli myśląc o dobrym wypełnianiu obowiązków, zbielałych kości naszych Bohaterów do dziś byśmy nie mogli odnaleźć w bezkresnym Sybirze.

Na problem KL Auschwitz, Holocaustu, czy sowieckiego ludobójstwa musimy spojrzeć szerzej. Musimy widzieć nie tylko sam obszar KL Auschwitz, ale również interpretacje i prezentacje takiego miejsca pamięci. Jest to bowiem nie tylko spopielały cmentarz, zabytki materialne będące szczytowym osiągnięciem inżynierii totalitaryzmu, do którego wielu się przymierzało, lecz jedynie Niemcom udało się to opanować w nowoczesny, technologiczny sposób. Interpretacja może również odnosić się i dotyczyć jakiejś ulicy, domu, sosny, czy brzozy, a może jakiego rowu, czy dołu gdzieś na Mazowszu, Syberii, czy Wołyniu, bo tam znajdujemy rozrzucone kości ofiar. Nie dotyczy to samych cmentarzy, czy miejsc pamięci. Problem jest znacznie głębszy, gdyż dotyczy naszej świadomość, nie tyle konstytuującej przeszłości i pamięć, lecz nas samych. Pozostała po nich nawet nie tyle pamięć, lecz znacznie coś więcej, bo świadomość zła. Spotkać się z takim miejscem to nie jest problem złożenia kwiatów czy modlitwy, to spojrzeć w otchłań, wejść do Hadesu. To introwertyczny dramat osobistych doznań dla tych, którzy to jeszcze pamiętają, a także dla tych, którzy się z tym może w sposób przypadkowy spotkali. To kwestia niezmywalnej krwi na rękach mordercy i świadomości rany doznanej nie indywidualnie, lecz zbiorowo. Okazuje się jednak, że nie jest to jedynie przeszłe wydarzenie, lecz obecna „postpamięć", której nie mogą się wyrzeknąć się sprawcy, zapomnieć ofiary i świadkowie. Ta „postpamięć”, jak to określiła Hirsch oddziałuje jako pokoleniowe przenoszenie pamięci, co nie tylko jest przywracaniem pamięci, lecz stałym życiem z nią. Nie jest to jedynie trauma wspomnień, lecz przekleństwo życia z tym. Nie są to tylko zabytki, czy okazjonalnie celebrowane miejsca pamięci, lecz międzypokoleniowy transfer dziedzictwa 


\section{Miejsce pamięci a przestrzenie pamięci

zła, do którego kolejne generacje ofiar, sprawców i świadków muszą się ustosunkować. Rolą konserwatora zabytków jest również zmierzyć się z tym problemem, który nie jest jedynie kwestią technologii konserwatorskiej, lecz szukaniem odpowiedzi na pytanie sięgające różnych przestrzeni dziedzictwa $\mathrm{w}$ aspekcie materialnym, niematerialnym duchowym i poza materialnym, sprawiając reakcje doznaniowe i uczuciowe, by z jednej strony umieć pomóc, a z drugiej potrafić zapobiec. Nie robimy tego dla siebie, lecz dla innych i tym samym musimy potrafić wyjść poza schematy. W analizie Pierre Nora istotnym jest fakt upamiętnienia, ale dla nas również forma upamiętniania. Bo to my musimy rozważyć koncepcję, formę i kształt ingerencji mogącej mieć istotny wpływ na przekaz tego rodzaju dziedzictwa. Nie na wszystko mamy wpływ, ale w swym zawodowym życiu musimy się mierzyć $\mathrm{z}$ wieloprzestrzennymi aspektami dziedzictwa, gdzie podjęte decyzje będą dalej kluczowymi. Z jednej strony mamy chronić stan zastany, dopuszczać kreacje, a z drugiej przeciwdziałać kreacjom, czy działaniom mogącym naruszyć stan takiego miejsca. Spotkaliśmy się już z tak różnymi formami agresji w stosunku do dziedzictwa martyrologii, że nic nie powinno nas już zaskoczyć. Coś co do niedawna nie mieściło się $\mathrm{w}$ głowie jest obecnie w kolejnym pokoleniu traktowane jako forma już wyrażona, która może być odskocznią do innego rodzaju czynów. Są to problemy, gdzie my konserwatorzy zabytków winniśmy być aktywnymi uczestnikami opracowując działania i analizując ich skutki $\mathrm{z}$ innymi.

My konserwatorzy nie mamy tego rodzaju obciążenia, bo podchodzimy do problemu w sposób zmechanizowany i pragmatyczny odpowiadając na problemy formalne i techniczne odnoszące się do materii przedmiotu naszego zainteresowania. Zapominamy, że choć może nie jesteśmy kreatorami wizji społecznych to poprzez nasze konserwatorskie kreacje i ochroniarskie decyzje wpływamy na nie. Z przykrością trzeba stwierdzić, iż jesteśmy mniej lub bardziej uzdolnionymi kreatorami prawa, które później chcemy społecznie wdrażać poprzez decyzje konserwatorskie i kreatywne realizacje wypełniające te decyzje. Wydaje się, że będąc namaszczonymi przez władzę, chcemy tę władze spełniać społecznie, zapominając że nie państwo, lecz społeczeństwo jest generatorem pamięci, a tym samym dziedzictwa. Państwo jako samoorganizacja społeczna, może tworzyć struktury by te dziedzictwo traktować formalnie lub emocjonalnie.

Mówiąc o przestrzeniach dziedzictwa musimy się oderwać od płaskiego pojmowania wydzielonego obszaru i widzieć to jako wzajemnie przecinające się kręgi różnie postrzeganego oddziaływania dziedzictwa, gdzie jedne kręgi będą silnie zdominowane przez materię, inne zaś będą inspirowane przez oddziaływanie o niematerialnym i pozamaterialnym charakterze. Niejednokrotnie obie te strefy będą się lączyći rozdzielać tworząc nowe możliwości podkreślając delikatne i niewidoczne, nie mniej silnie oddziaływać na materię, a czasami stanowić o niej samej. W tym całym układzie jeśli jesteśmy otwartymi odbiorcami, którzy gotowi są przyjmować coraz więcej możemy stworzyć cały kompleks wiedzy i doznań.

Miejsce na globie Ziemia może mieć różnorodną formę, może być wodą lub lądem. Tym lądem niech będzie topograficznie określone miejsce gdzieś na północnej półkuli, zwane Polską, gdzie w południowej jej części wylądują nasi kosmiczni goście. Pod względem materialnym znajdą tutaj mieszankę drobin organicznych i nieorganicznych zwaną glebą, będącą podłożem 
życia organicznego. W glebie znajdą materialne pozostałości wykonanych struktur budowalnych korzystających z cegły, kamienia, desek, bali drewnianych, betonu i drutu, od czasu do czasu spotkają tutaj jakieś struktury wystające z niej. Trochę zaskoczenia wzbudzić może fakt, że jedne pomieszczeniami są napchane tymi samymi przedmiotami, a inne są puste. Taki opis miejsca dokonałby przybysz z innej planety spacerując po KL Auschwitz. Jeśli ten przybysz miałby odpowiednie instrumentarium ocenił by stan zachowania widzianych elementów i może mógłby ogólnie ocenić cel poszczególnych obiektów. Z pewnością zainteresowałyby go jakieś dokumenty. Tekstów może by nie mógł przeczytać, stare zdjęcia może udałoby mu się zinterpretować, lecz zobaczonych przedstawień trudno by mu było zrozumieć. Co zrobić gdy tego rodzaju informacje stają się rozproszone i chociaż dotyczą jednej lokalizacji i tego samego okresu należy szukać związku między nimi, bo tylko taki przekaz ukazuje głębię problemu stanowiącego o przekazie i odbiorze pamięci?

Tutaj chciałbym się podzielić własną interpretacją kilku elementów konstytuujących „miejsce pamięci” jakim jest KL Auschwitz. Będą to obiekty materialne kreujące niematerialny i pozamaterialny przekaz. Każdy z tych elementów jest różnie lokowany. Dotycząc tego „miejsca pamięci” w jakiś sposób wzajemnie się dopełniają, jeśli spojrzeć na nie z szerszej perspektywy. Mają ono wartość tworzenia przestrzennych pól oddziaływania, pod warunkiem, że będziemy wrażliwi na ich niematerialny czy też pozamaterialny przekaz.

\section{Washington, Holocaust Museum}

Zdjęcie którego nie zrobiłem, a może mimo wszelkich przeciwskazań powinienem zrobić, by móc z państwem się dziś nim podzielić. Gdybym je wykonał, przedstawiałoby grupę amerykańskiej roześmianej i ubawionej młodzieży, przy wyskalowanym modelu przekroju przez komorę gazową w KL Auschwitz. Ten śmiech pojawiał się na twarzy czarnej, białej i żółtej młodzieży gdy wskazywali sobie palcami co ciekawsze naturalistyczne figurki więźniów wykrzywionych w konwulsyjnych grymasach śmierci. Jedni już byli martwi, inni się dusili, drudzy zorientowali się co ich czeka, a ci na końcu przy samych zamkniętych drzwiach, jeszcze pogodni, bo znając niemiecką zasadę Ordung must sein oczekiwali, że po trudach podróży zażyją prysznicu, tak jak było im to powiedziane. Same figurki wykonane były w białej masie gipsowej, brak im było naturalizmu znanych dzieciom figurek Barbi i Kena. Gdy zobaczyłem tę scenę byłem zszokowany koncepcją artystycznej prezentacji w muzeum, tak dbającym o autentyzm artefaktów, że były tu sprowadzane oryginalne obiekty z samego KL Auschwitz. Lecz ta drastyczna scena jaką zobaczyłem dała mi aspekt różno wymiarowych przemyśleń, odnośnie tego czego nie ma już pod tym adresem. Dramatu, który musimy sobie wyobrażać i w jakiś sposób doznać, by móc starać się go zrozumieć. 
Miejsce pamięci a przestrzenie pamięci $\square^{43}$

\section{Berlin, Museum of Terror}

Zdjęcie przedstawia grupę rozbawionych pań i panów w czarnych mundurach, zażywającej wolnej chwili. Gdyby nie podpis pod zdjęciem pewnie byśmy się nie zorientowali, że zdjęcie wykonano gdzieś nad Sołą, koło KL Auschwitz. Trudno jest tylko określić moment, czy zrobiono je przed, czy już po wykonaniu służbowych obowiązków w zakładzie, gdzie praca wyzwala. Zdjęcie to ukazało mi tę radosną stronę miejsca pamięci, której nie powinniśmy pomijać, lub zbywać w prezentacji dziedzictwa. Należy z przykrością stwierdzić, iż aparat Leica, który mieli Niemcy dla bieżącego dokumentowania, był trudno dostępny dla towarzyszy radzieckich, bo pewnie podobne ujęcia moglibyśmy zobaczyć gdzieś z okolic lasku katyńskiego. Pewnie zobaczylibyśmy tu również grupę umundurowanych mężczyzn i pań zadowolonych z dobrze wykonanego obowiązku służbowego.

\section{KL Auschwitz, Muzeum}

Następne zdjęcie jakie tutaj przywołuję pochodzi ze zbiorów Muzeum w Auschwitz jakie w 1997 roku oglądałem wraz z profesorem Januszem Bogdanowskim uczestnicząc w pracach Programu Oświęcimskiego, które miały służyć nowemu waloryzowaniu obiektów obozu i wytyczeniu tzw. strefy buforowej. Amerykańskie zdjęcie lotnicze ukazywało w doskonałej jakości cały obóz. Refleksja jaką wyraził profesor brzmiała „Panie Marku, tu nie ma żadnych drzew”. Chwilę po tym zdaniu pojawiła się moja refleksja „No tak, to nie miat być obóz wypoczynkowy, lecz piekło na ziemi", tak by z kawałka cienia, czy nawet kwitnienia drzewa więźniowie nie czerpali przyjemności. W tym momencie cała dyskusja o wyznaczaniu stref buforowych dla mnie spadła na margines, bo nie trzeba by było wyznaczać stref, lecz przybliżyć odwiedzającym koszmarny wygląd miejsca poprzez wycięcie drzew i krzaków w tej strefieśmierci i sam widok piekła odgrodziłby to co kiedyś było obozem. Wykreowanie na terenie obozu przez lata przestrzeni z zielenią dało asumpt do zagarnięcia jego obszaru z naszej świadomości. Jeżeli Obóz ma nie tyle upamiętniać, lecz przemawiać do nas współczesnych winniśmy zadbać o jego pozamaterialny wymiar odczuwania, a nie tylko przemawiania.

\section{Berlin, Anhalterbanhof}

Zdjęcie przedstawia zrujnowaną elewację dworca Anhalter w Berlinie. Ta ruina upamiętniająca zniszczenia wojenne w stolicy III Rzeszy wzbudziła moje zainteresowanie tym miejscem od momentu kiedy w roku 1988 po raz pierwszy zobaczyłem instalację performerską $\mathrm{z}$ wywróconą do góry nogami lokomotywą. Wtedy w kontekście ruiny frontonu dworca anhalterskiego było to jakieś sugestywne odniesienie do tego co przyniosła tutaj wojna. Ten materialny wymiar performacji oddziaływał na emocje i odczucia widza. Te miejsce w jakiś sposób mnie inspirowało i za każdym razem gdy odwiedzałem Berlin udawałem się tam. Jednak za kolejnym razem już nie zobaczyłem lokomotywy, lecz doskonale opracowany produkt konserwatorski. Zewnętrzny fragment elewacji został konserwatorsko opracowany z przywróceniem jego dawnego wyglądu i pełnym zabezpieczeniem struktury muru przed 
penetrującą wodą deszczową, zaś strona wewnętrzna ściany zachowana została zgodnie ze stanem z 1945 roku. Obiekt ten ukazywał swoją tragiczną historię poprzez ruinę zachowującą stan zniszczenia wewnętrznej elewacji. Ta dwoistość stanów zachowania była jakąś interpretacją historii zabytku podkreślającą jej tragiczny wymiar, jak i potęgę dawności tej budowli. Moje kolejne spotkanie z tym zabytkiem przyniosło zauważenie intrygującej planszy informacyjnej, na której oznaczono daty dzienne i ilości Żydów wywożonych z Berlina, w tym również do KL Auschwitz. Precyzja informacji tutaj zawartej porażała w dwójnasób. Zarówno informacją o kolejnych datach transportu odbywających się co parę dni, jak i precyzyjnym odliczaniem pasażerów. Zawsze sto, ani jednej mniej, ani więcej. Kłopot zrobił się jedynie w przypadku kilku ostatnich transportów, bo jakoś nie można już było zebrać do czasu odjazdu pociągu kompletu pasażerów. Te precyzyjne historyczne odniesie stało w kontraście do tego co nas spotkało, gdy likwidacja i zniszczenie miały następować masowo i szybko, aż do osiągnięcia stanu możliwości systemu. W Berlinie, stolicy perfekcyjnych Niemców wszystko miało być odliczone co do sztuki, ani więcej, ani mniej i być gotowe na czas.

Ten prosty kontekst przypadkowych spotkań z miejscem pamięci jakim jest KL Auschwitz wykazuje konieczność świadomego tworzenia relacji pomiędzy samy zabytkiem, topograficznie określonym, a całą jego otoczką, na którą składają się czasami przypadkowe formy upamiętniające $\mathrm{w}$ różnych miejscach. Kreują one przestrzenie naszych odniesień i stosunku do tego miejsca i pamięci. W dzisiejszym podejściu rozszerzającym dotychczasowe formy przekazu winniśmy świadomie wyjść naprzeciw spotkaniu z dziedzictwem. Nie oznacza to jednak by ulega formom popkultury, czy prostej szkolnej edukacji, lecz postrzeganiu tego dziedzictwa w wieloaspektowych przestrzeniach oddziaływujących na nas indywidualnie i zbiorowo. Na takie spotkania z przestrzeniami dziedzictwa jeszcze nie jesteśmy przygotowani zawodowo. Może brak nam odwagi by ukazać kontrast miski więźniarskiej w śmierdzącym baraku z porcelanową zastawą na białym obrusie w kantynie oficerskiej. Jeśli chcemy w świadomy i pełny sposób umieć się odnieść do tego dziedzictwa, musimy potrafić się odrywać się od kwestii autentyzmu materii na rzecz wierności pamięci. Autentyzm materii winien być interpretowany, by przywróci stan tragedii.

Kolejne spotkanie z KL Auschwitz nastąpiło gdy czytałem publikację Johna Stubbsa i Emily Makas $^{18}$. Wśród istotnych projektów konserwatorskich mających znaczenie w skali świata wymienił on trzy polskie zabytki. Odbudowę Warszawy, drewniane kościoły Małopolski i KL Auschwitz, który co ciekawe nie został przypisany Polsce, lecz został wydzielony w podrozdziale gdzie przedstawiono problemy ochrony dziedzictwa europejskich Żydów. Jak zauważyli to autorzy piętno wojny wyraźnie odznaczyło się w polskim podejściu konserwatorskim stało się częścią nie tylko naszej historii, lecz światowego dziedzictwa. Z faktem tym wiąże się konieczność dbania o te dziedzictwo, które winno być widziane w szerokich jego przestrzeniach. Nie my je wykreowaliśmy, lecz nam zostało ono powierzone.

18 J. H. Stubbs, E. G. Makas, Architectural Conservation in Europe and Americas: national experience and practice, Willey, Hoboken 2011, s. 255-256, 258-268; M. Barański, J. H. Stubbs, E. G. Makas, wstęp M. Bouchnaki, Architectural Conservation in Europe and the Americas: national experience and practice, w: Wiadomości konserwatorskie, 26, 2011, s. 165-166. 


\section{Miejsce pamięci a przestrzenie pamięci

Na tym chciałem zakończyć moje przemyślenia, lecz okazało się iż w tym samym czasie w innym miejscu Europy, w Sztokholmie, ktoś, kogo nie można posądzać o żadną stronniczość oceny, polono- czy judeocentryzm myślenia, wypowiedział się publicznie $\mathrm{w}$ interesującym nas temacie. Był to pisarz Kazuo Ishiguro, laureat Literackiej Nagrody Nobla 2017, który 7 grudnia w swoim wykładzie „My Twentieth Century Evening and Other Small Breakthroughs” dotyczącym różnych życiowych odniesień mających wpływ na jego twórczość, przypomniał wizytę w KL Auschwitz w 1999 roku $^{19}$. Przybył tam będąc zaproszonym przez International Auschwitz Committee. Warto poznać jego przemyślenia z tej wizyty bo odnoszą się do problemu przekazu tego miejsca. „Czułem, że zbliżyłem się do serca ciemnej siły, w której cieniu dorastało moje pokolenie. W Birkenau w dżdżyste popołudnie stałem przed ruinami komór gazowych - obecnie dziwnie pozostawionych i zaniedbanych, tak jak Niemcy zostawili je po wysadzeniu przed nadejściem Armii Czerwonej. Ruiny były mokre, pokruszone i wystawione na ciężki klimat Polski rozpadając się z roku na rok". Trójka więźniów jego opiekunów podzieliła się swymi dylematami prosząc go o opinię. „Czy te pozostałości powinny być chronione? Czy należy budować przezroczyste kopuły aby je zachować dla oczu przyszłych pokoleń? Czy pozwolić im powoli i naturalnie rozpaść się w nicość?" Nie mogąc odpowiedzieć wprost zrozumiał, że pytania stają się metaforą i konstytuują większe dylematy. „Jak zachować takie wspomnienia? Czy szklane kopuły przekształcą te relikty zła i cierpienia w eksponaty muzealne? Co winno być wybrane dla zachowania i pamięci ? O czym właściwie powinniśmy pamiętać? Kiedy jest lepiej zapomnieć, by iść naprzód?" Jak wspomina wtedy miał 44 lata i dotychczas rozważał II Wojnę Światową, jej koszmar i triumfy, jako coś przynależne do pokolenia rodziców. Uświadomił sobie, że wiele z tych świadectw i zdarzeń wkrótce umrze i pojawily się pytania. „Co potem? Czy ciężar pamiętania powinien spaść na moje pokolenie? Przecież my nie przeżyliśmy tych lat wojny, choć dorastałem z rodzicami ukształtowanymi przez te wydarzenia. Czy teraz jako pisarz winienem podjąć obowiązek, nie będąc go świadomy? Obowiązek przekazania najlepiej jak mógłbym tej pamięci i lekcji pokolenia rodziców, tym którzy przyjdą po nas." Kontynuując wspomina spotkanie w Tokyo, gdy spytano go o kolejną książkę, czy byłby gotów podjąć temat złych i wstydliwych wspomnień. Wtedy, udzielając odpowiedzi zrozumiał, że nie jest przygotowany do odpowiedzi, lecz odpowiedział pozytywnie, że gotów jest napisać książkę jak naród, czy społeczeństwo odnosi się do swych wspomnień i zapomnienia. Pojawiły się pytania „Czy naród zapomina i pamięta mniej więcej w taki sam sposób jak jednostka? Czy istnieją jakieś ważne różnice? Czym dokładnie są wspomnienia narodu? W jaki sposób je opisać? Gdzie są one przechowywane? W jaki sposób są one kształtowane, kontrolowane? Czy warunek by zapomnieć jest jedynym sposobem, aby przerwać przemoc, czy zatrzymać rozpad społeczeństwa zmierzającego w otchłań chaosu i wojny? Z drugiej strony, czy stabilne i wolne narody mogą być rzeczywiście budowane na fundamencie świadomej amnezji i frustrującej sprawiedliwości? Odpowiadając pytającemu, usłyszałem w sobie głos, że chciałbym znaleźć sposób by opisać te kwestie, ale w tym momencie na nieszczęście nie mogę nawet przemyśleć jak to zrobić."

Kazuo Ishiguro urodził się w 1954 roku w Nagasaki, miejscu nie mniej tragicznym,

19 K. Ishiguro, Nobel Lecture: My Twentieth Century Evening and other Small Breakthrougs, //www.nobelprize. org/nobel_prizes/literaturę/lauteates/2017/Ishiguro -lecture_en.html. 
naznaczonym wojną i śmiercią, lecz może poprzez swą skromność w formułowaniu wspomnień na międzynarodowym forum nie odniósł się do tego „miejsca pamięci”. Przedstawił jednak problemy również żywe dla nas, jego rówieśników.
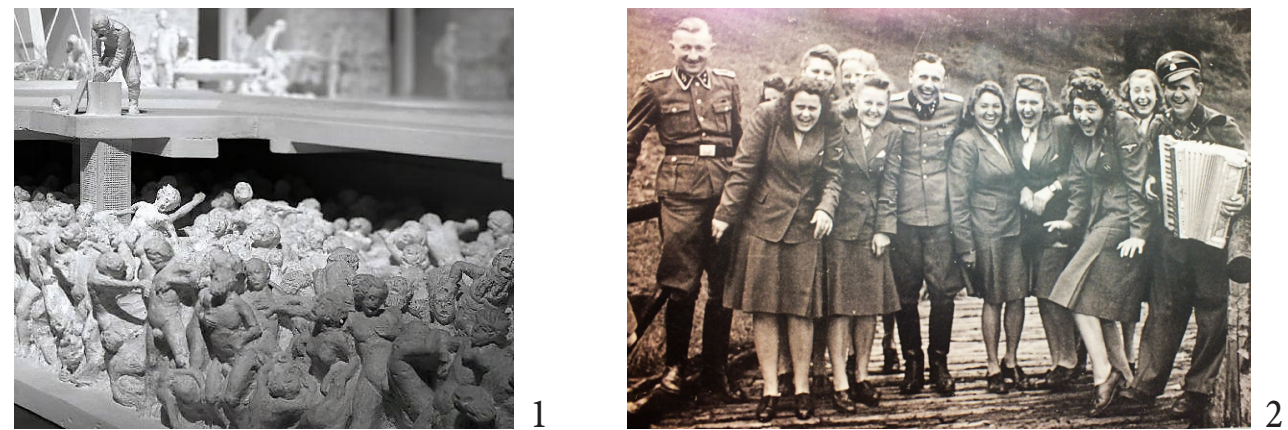

Ryc. 1 Washington, Holocaust Muzeum. Fragment ekspozycji. (fot. archiwum)

Ryc. 2 Berlin, Muzeum Terroru, Załoga KL Auschwitz na wycieczce. (fot. archiwum)
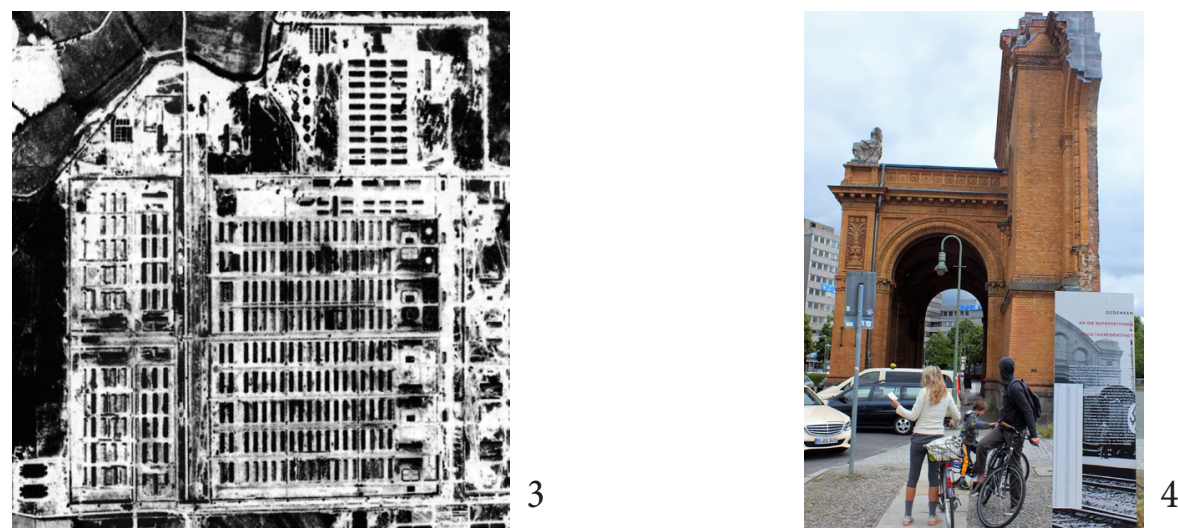

Ryc. 3Kl Auschwitz, Muzeum. Zdjęcie lotnicze obozu z 1944 roku. (fot. archiwum) Ryc. 4 Berlin, Ahhalterbanhof. Ruina z planszą informacyjną. (fot. M. Barański) 